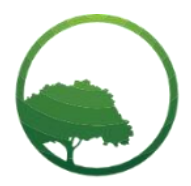

Research in Business \& Social Science

IJRBS VOL 10 NO 6 ISSN: 2147-4478

\title{
Tourism education enrolment among Kenyan public universities: Socioeconomic aspects
}

\author{
(D) Margaret Mungai ${ }^{(a) *}$ (iD) Damiannah Kieti ${ }^{(b)}$ (i) Isabella Mapelu ${ }^{(c)}$ \\ (a) Tutorial Fellow, School of Business, Karatina University- Main Campus, Nyeri, Kenya \\ (b) Prof., School of Tourism, Hospitality, and Event Management, Moi University- Main Campus, Eldoret, Kenya \\ (c) Ph.D., School of Tourism, Hospitality, and Event Management, Moi University-Main Campus, Eldoret, Kenya
}

\author{
A R T ICLE INFO \\ Article history: \\ Received 27 August 2021 \\ Received in rev. form 17 Sep. 2021 \\ Accepted 19 Sept 2021 \\ Keywords: \\ Socio-economic factors, Enrolment, \\ Tourism Education, Students' Choice \\ JEL Classification: \\ O15; P36
}

\begin{abstract}
A B S T R A C T
The paper innovates on the existing literature and field data by assessing the socio-economic factors influencing the enrolment decisions of students, to tourism programs among 12 selected Kenyan public universities. The study uses a descriptive design. A structured questionnaire and an interview guide were used to gather data from 192 students and 12 departmental heads. The study used a multisampling technique; purposive sampling was adopted to select the universities, while simple random sampling was used to determine students pursuing a degree in tourism management. Data collected were analysed using SPSS. A structural equation model was used for data analysis, following exploratory factor analysis and confirmatory factors analysis. The logit regression results reveal the existence of a statistically significant relationship between socioeconomic factors and students' choice to enroll in tourism programs. The most important reasons influencing the student's tourism degree choice are tuition fees, employment prospects and parents/family background. The study recommends that education practitioners, scholars, governments, and private sectors allocate resources and dedicate efforts to improving and tourism awareness among high school students. Future research should investigate the same study variables using longitudinal and in-depth approaches to minimize generalizability concerns related to the study findings.
\end{abstract}

(C) 2021 by the authors. Licensee SSBFNET, Istanbul, Turkey. This article is an open access article distributed under the terms and conditions of the Creative Commons Attribution (CC BY) license (http://creativecommons.org/licenses/by/4.0/).

\section{Introduction}

The cumulative factors influencing a student's career path emanate from both external and internal surroundings; the cost and availability of financial aid, aspirations, aptitude, and social factors (Owusu et al., 2018). This belief is anchored on various theoretical foundations like the human capital theory, which ties empirical evidence among psychological, demographic, and social/cultural-economic factors influencing the enrolment decision to a specific program in institutions of higher education [IHEs] (Gichuhi \& Kibui, 2015). Moreover, the degree of importance students attach to these factors is contextual-based.

Kenyan tourism education is dynamic, a mixture of gradual changes, depicting an education system logged by many issues. The Kenyan government realized the potential of the tourism sector in the economic development in the late '70s (Mayaka \& Akama, 2007,2015). At this juncture, the Kenyan government established the Kenya Utalii College in 1975; a joint project with the Swiss Agency for Development and Cooperation, as a fully-fledged hospitality and tourism training institution to train management staff for the industry (Atef et al., 2019). Since then, the country has witnessed the mushrooming of public and private universities, colleges, and polytechnic, endeavoured to teach and train tourism-related courses.

In terms of enrolment, public universities have been registering double-folds between 2012 and 2015 (Commission of University Education [CUE], 2016). For example, total enrolment in public chartered universities sprouts from 363,334 to 456,926 students, between 2014 and 2018, representing a 25.76\% increase in enrolment (CUE, 2018). Concurrently, the Kenyan government has

* Corresponding author. ORCID ID: 0000-0002-8422-0419

(C) 2021 by the authors. Hosting by SSBFNET. Peer review under responsibility of Center for Strategic Studies in Business and Finance. https://doi.org/10.20525/ijrbs.v10i6.1367 
implemented mechanisms to streamline the rate of enrolment. Among them, the introduction of free primary education in 2003 and the oblivion of several policy documents, including the Kenya Vision 2030, Sessional Paper No. 14 of 2012, Sessional Paper No.2 of 2015, and the Big 4 Agenda of 2018, all aimed to boost the tourism enrolment among institutions of higher learning. Despite these efforts, tourism as a program has always been categorized among the Business and Administration category since 2014 (see table 1), which does not give an ideal picture of tourism, as a stand-alone program.

Table 1: Enrolment Rates for the period 2015-2018

\begin{tabular}{llll}
\hline Enrolment Aspects & $\mathbf{2 0 1 5 / 1 6}$ & $\mathbf{2 0 1 6 / 1 7}$ & $\mathbf{2 0 1 7 / 1 8}$ \\
\hline Public and Private Universities Enrolment & 539749 & 547316 & 538820 \\
\hline Public Chartered Universities Enrolment & 461820 & 458946 & 456926 \\
\hline Bachelor Degree Enrolment & 409222 & 409927 & 368100 \\
\hline Program by cluster (Business and Administration) & 110 & 152 & 149 \\
\hline
\end{tabular}

Pointedly, despite the higher enrolment rate, the desire for equitable and accessible university education has resulted in the exponential growth of universities. CUE has, over the years, enhanced efforts in assuring education quality and regulating enrolment cluster-point requirements for various university programs, to achieve national and global competitiveness. However, a general concern in the university sector in Kenya has been the issue of substantial graduate unemployment (Kenya National Bureau of Statistics [KNBS], 2020); the imbalance between humanities, Arts and Social sciences on the one hand, and Science, Technology Engineering, and Mathematics [STEM] on the other, and the consequent shortage of needed knowledge and skills in areas such as manufacturing, housing, health, food security, biotechnology and information communication technology, CUE (2016).

A question then arises, as to why students in Kenya prefer the tourism program, despite the private sector and the Kenyan government seemingly encouraging students' enrolment in STEM courses. That scenario underscores the need for further research, particularly on the socio-economic context. This study, therefore, revisits the enrolment decision debate by exploring the socio-economic factors influencing university students' tourism program enrolment decisions within the selected public universities in Kenya.

\section{Literature Review}

\section{Theoretical and Conceptual Background}

The demand for higher education has grown in most countries due to increased populations, economic difficulties, and increasing pressures on public budgets. This has resulted in shifting the burden of paying tuition fees from the government to the students. In cognizant of this notion, for example, the university education in Kenya began in 1963, and it was offered free, covering tuition fees and living expenses (Weidman, 1995). The free university education lasted until 1991 when the government introduced a cost-sharing policy, where parents were expected to cover the tuition fees and living expenses. To that effect, the government established a student loan program, the higher education loans board (HELB), to enable needy students to access higher education (Sanyal \& Martin, 1998).

In line with this thought, the cost of studies, career prospects, parental influence, employment, and income opportunities, have been considered essential socio-economic factors influencing enrolment (Tadaro \& Smith, 2015), which follows the econometric model. Econometric models typically view college attendance as an economic benefit, where students pursue higher education because of the perceived benefits, based on expected costs, expected future earnings, college characteristics, and students' characteristics. Interestingly, when the unemployment rates increase, individuals thereof pursue higher education even when the expected level of income is minimal as a way of escaping unemployment (Saroush et al., 2015).

Graduate employment is one of the criteria used to evaluate the success of pursuing higher education. Many students pursue higher education so that they can become economically stable. Therefore, undergraduates view higher education as a pathway to conquering the barriers through enhanced career opportunities, greater earning potential, and obtain knowledge and expertise in their career paths (Chan et al.,2014). Avery \& Turner (2012) allude that a bachelor's degree program remains a good investment for individuals and society, for the country's economic health and economic competitiveness of a community.

Enrolment is also sensitive to the availability of financial aid, especially among individuals with lower family incomes. When investigating a family background, three issues are pertinent; income, education, and occupation (Ekpo \& Igiri, 2015; Li \& Qiu, 2018; Lyu et al., 2019). Low-income families may wish for their children to pursue higher education, which may not be possible because they may not afford to pay tuition fees. On the other hand, affluent families usually plan for their children to further their studies because they can afford them, which means that the family income influences students' enrolment for higher education. Changes in the family income may directly impact the students who may choose to enrol in cheaper programs or even leave education altogether. 
Idealized by the human capital theory, the belief is that education increases an individual's human capital. Therefore, parents with a high level of human capital tend to earn more income and access financial resources. It then makes them able to support their children through post-secondary education decisions (Kromydas, 2017). The complete statement of this theory is found in Becker \& Tomes (1986), where utility-maximizing parents are concerned about the welfare of their children. The model assumes that the degree of intergenerational mobility is determined by the interaction of utility-maximizing behaviour with investment-consumption opportunities in different generations. However, Haveman \& Wolfe (1995) criticize the Becker and Tomes model stating that it yields little empirical guidance because it addresses a few family-based determinants of investments in children. The various attributes of enrolment decision-making from the literature are well summarized in Table 2.

Table 2: Summary of the literature review

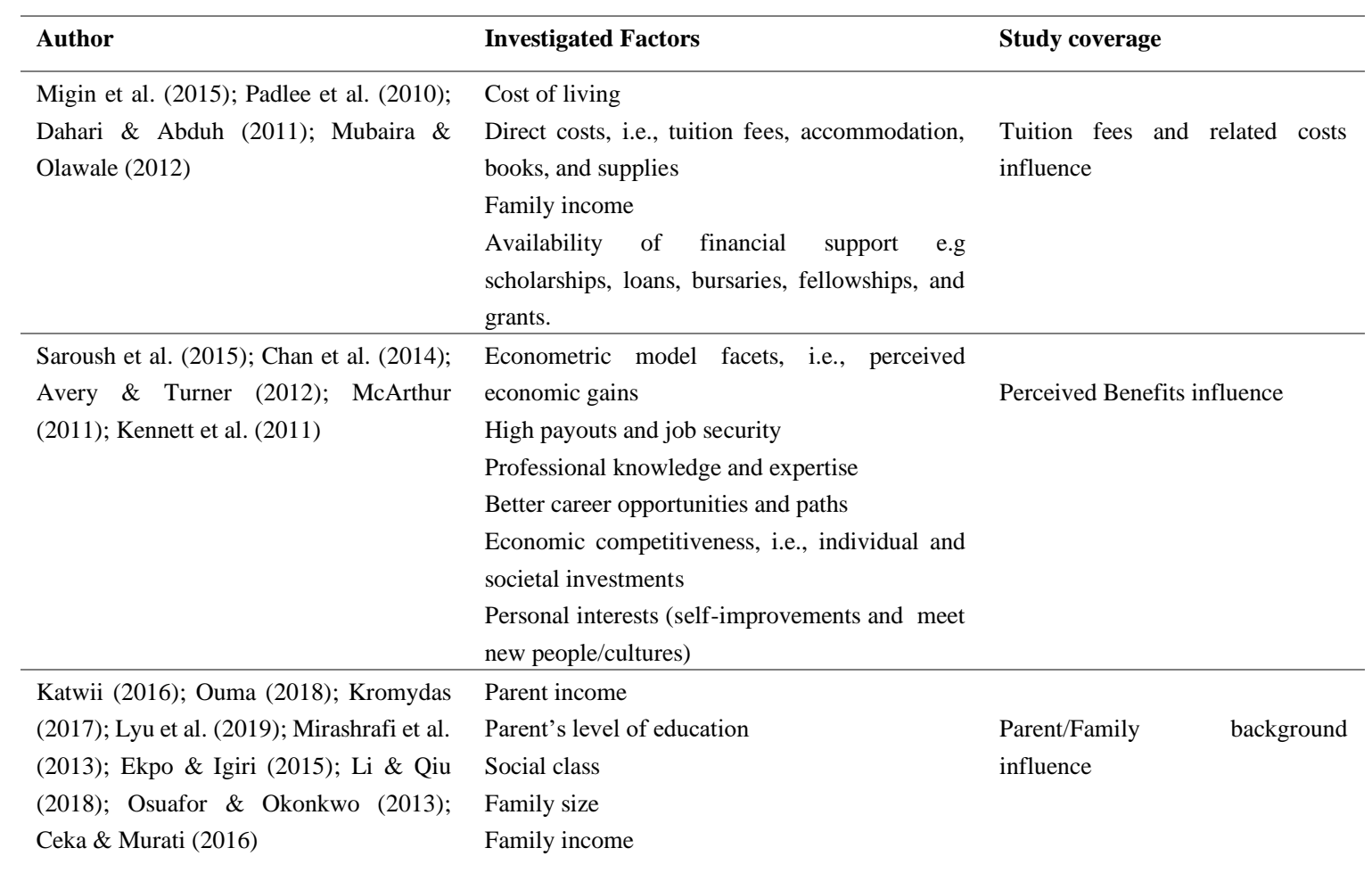

\section{Underpinning Theory}

The concept of human capital theory [HCT] considers direct and opportunity costs as the principal determinants of education demand. The theory posits that one chooses the optimal length of schooling to maximize the present value of the net lifetime wealth, and in this case, the choice of program to enrol (Becker, 1967, 1962; Fleischhauer, 2011; Gichuhi and Kibui, 2015; Teixeira, 2014). Education as an investment usually affects increased career opportunities, more chances of earning higher salaries, increased individual productivity, a more fulfilling work environment, learning essential skills, and a lower probability of unemployment (Tytingvåg, 2015). Education is therefore assumed to be an investment where individuals derive utility (Manono et al., 2013). HCT plays a vital role in enrolment management as it provides a conceptual basis for student enrolment decision-making (Barwick et al., 2021). This then manifests as a catalyst, as the socio-economic desire becomes feasible if the expected gains after graduation are immense.

\section{Research \& Methodology}

The study used an explanatory-descriptive design; triangulation of both qualitative and quantitative techniques. A structured questionnaire with 14 items, was randomly distributed among 192 first-year students of 2017/2018 academic year, and an interview guide to 12 heads of department, all from 12 purposively selected public universities offering tourism degrees.

The questionnaire used a 5-Likert scale point, from 1(strongly agree) to 5(strongly disagree). Face-to-face and zoom interviews, and email and physical questionnaire distribution were used to gather primary data, while secondary data came from reviewing relevant literature. Data collected were analyzed using SPSS.

A structural equation model was used for data analysis, following a two-stage framework; confirmatory factors analysis and exploratory factor analysis. 


\section{Findings and Discussion}

\section{Descriptive Statistics}

Table 3 provides a general profile descriptive statistic on socio-economic factors that influence the enrolment of the tourism course. SEF1 (respondents satisfied with the offer of a place on tourism education) sub-variable had the highest mean of 3.82. Further sub variable SEF11 (respondents' parents' educational background influenced them to study tourism) had the lowest mean of 1.91 . Among the respondents highly recognized, the three socio-economic attributes included employment opportunities (M=2.94, $\mathrm{SD}=1.246)$ and promotional opportunities $(\mathrm{M}=2.90, \mathrm{SD}=1.073)$. On the lower end, high school teachers and counsellor's influence $(\mathrm{M}=2.17, \mathrm{SD}=1.246)$ and Course fees $(\mathrm{M}=2.94, \mathrm{SD}=0.954)$ represented among the bottom three items with the lowest mean and standard deviations.

Table 3: Socioeconomic Descriptive Statistics

\begin{tabular}{|c|c|c|c|}
\hline & Socio-economic factors Items (SEF) & Mean & Std.Deviation \\
\hline SEF1 & I was delighted with the offer of a place in tourism education & 3.82 & .954 \\
\hline SEF2 & My examination result only qualified me for a tourism course & 2.22 & 1.001 \\
\hline SEF3 & The tourism industry provides more employment opportunities than other industries & 2.94 & 1.246 \\
\hline SEF4 & $\begin{array}{l}\text { The tourism industry offers more significant promotional opportunities than other } \\
\text { industries }\end{array}$ & 2.90 & 1.073 \\
\hline SEF5 & Working in the tourism industry provides a secure future & 2.88 & 1.194 \\
\hline SEF6 & The starting salary expected after graduation is high & 2.23 & .954 \\
\hline SEF7 & $\begin{array}{l}\text { The number of alumni who have attained employment upon graduation attracted } \\
\text { me to study tourism }\end{array}$ & 2.49 & 1.176 \\
\hline SEF8 & The course fees for tourism education influenced my choice of tourism education & 2.02 & .954 \\
\hline SEF9 & In choosing tourism education, financial assistance was an essential factor for me & 2.79 & 1.299 \\
\hline SEF10 & My parents' income encouraged me to study tourism & 2.09 & 1.122 \\
\hline SEF11 & My parents' educational background influenced me to study tourism & 1.91 & .977 \\
\hline SEF12 & My close friends encouraged me to study tourism & 2.43 & 1.221 \\
\hline SEF13 & My high school teachers and counsellors encouraged me to study tourism & 2.17 & 1.047 \\
\hline \multirow[t]{2}{*}{ SEF14 } & My siblings encouraged me to study tourism & 2.18 & 1.093 \\
\hline & Valid N (listwise) & 192 & \\
\hline
\end{tabular}

Another finding from social-economic was based on career marketability, and the role played by parent's wealth status in influencing their children's career paths, as echoed by one interview respondent:

...Besides wanting to attain self-actualization, many people pursue a course based on marketability, tied to future job securities. In other families, parents will pursue and even make their children love what they do... not only that, some parents are wealthy hence influencing students to follow their career path of wish, in short, the dictate the career paths of their children ........[HOD07]

Another respondent looked at the costs attributed to the course choice as a key basis for a larger large influx of students into Kenyan universities pursuing tourism courses:

... considering many families in Kenya are below the poverty level, students from such families tend to choose a course with lower tuition fee costs, like tourism and other business-related courses.... despite the County governments government, tuition fee for some courses like medicine is unmanageable by such students...... then following their perceptions or even consultation from parents, they end up settling for cheap courses...[HOD09]

Regarding parents' education level influence, three respondents gave contradicting views in the Kenyan context, poverty levels and levels of parents' income, psychologically demeanour students, though not always, to choose fairly inexpensive university programs to ensure they do not overburden their parents in an already harsh life.

..(1) In my opinion, it is a mixed perception... From my village, the underprivileged parent, those who couldn't go beyond primary school level, their children have become victorious and pursue high-end courses like medicine, law, and medicine..... [HOD07] ...(2) This can be both ways. Some parents due to lack education knowledge, do not know the difference between university courses; beyond the conventional community thinking. Thus their children end up choosing courses based on their grades, and not what parents tell them...[HOD03]...(3)... For my case as an example, my parents pushed me to take tourism because my father had done a tour guiding course at Utalii College in the '70s... I can vividly agree that parents' educational level and experiences at one point pose a great influence on their child's career path like mine....[HOD08]. 


\section{Structural Equation Modelling (SEM)}

SEM followed a two-phase process consisting of a confirmatory measurement model and a structural model (Byrne, 2016). The first phase involved estimating the measurement model, which assesses the relationship between the observable variables and the theoretical constructs they represent. The second phase was the specification of the structural model and evaluation of the relationships proposed, and testing of the hypothesis (Fan et al., 2016). The first stage of SEM involved CFA that evaluated the measurement model on multiple criteria; internal reliability, convergent, and discriminant validity. Before this, exploratory factor analysis [EFA], whose key steps included the computation of the factor loading matrix, was conducted. EFA was used to identify factors based on data and maximize the variance explained (Orcan, 2018). Before the EFA, two statistical tests that assess the suitability of data for structure detection were performed: the Kaiser-Meyer-Olkin [KMO] measure of sampling adequacy and Bartlett's Test of Sphericity. Table 4 indicates the test results for the suitability of structure detection, where the KMO value was 0.711, which is close to 1 . This means factor analysis was suitable $(\mathrm{p}<0.05)$ (Cronk, 2018).

Table 4: Test for Suitability of the Structure Detection

\begin{tabular}{|c|c|c|}
\hline KMO Measure of Sampling Adequacy & Bartlett's Test of Sp & \\
\hline 0.711 & $\begin{array}{l}\text { Approx. Chi-square } \\
\text { df } \\
\text { Sig. }\end{array}$ & $\begin{array}{l}718.126 \\
242 \\
0.000\end{array}$ \\
\hline
\end{tabular}

The Factor-loading matrix or a pattern matrix, shown in table 1.5, contains the loadings used to express the items in terms of the factors, interpretation of factors. The more the factors, the lower the pattern coefficients as a rule since there were more. In this study, the pattern matrix coefficients ranged from 0.561 to 0.987 after the items lacking factor loadings (SEF1, SEF3, and SEF7) were eliminated. The remaining variables are almost perfectly related to a factor pattern and were used to calculate the average index for the composite variables for hypothesis testing.

Table 5: Cross Loadings for the Measurement Model

\begin{tabular}{|c|c|c|c|c|c|c|}
\hline \multicolumn{7}{|c|}{ Factor Loadings } \\
\hline & 1 & 2 & 3 & 4 & 5 & 6 \\
\hline SEF2 & .623 & & & & & \\
\hline SEF13 & & .723 & & & & \\
\hline SEF12 & & .671 & & & & \\
\hline SEF14 & & .561 & & & & \\
\hline \multicolumn{7}{|l|}{ SEF8 } \\
\hline SEF6 & & & .602 & & & \\
\hline SEF5 & & & .618 & & & \\
\hline SEF10 & & & & .697 & & \\
\hline SEF11 & & & & .691 & & \\
\hline SEF4 & & & & & .997 & \\
\hline SEF9 & & & & & & .593 \\
\hline
\end{tabular}

***Extraction Method: Maximum Likelihood.

***Rotation Method: Promax with Kaiser Normalization

The second phase involved latent variables in testing the hypothesized relationships and to fit the structural model. To ascertain that the model provided a good fit for the data, the study considered a minimum of four tests of model fit that need to be deemed to be postulated by Hair et al. (2010). Apart from picking the four most widely respected and reported fit indices, the study picked on Root Mean Square Error of Approximation (RSMEA), Comparative fit index (CFI), Chi-square $\left(\mathrm{X}^{2}\right)$ to the degree of freedom (df), which is the traditional measure for evaluating overall model fit, where it is accompanied with a p-value less than 0.05 . Incremental fit indices (IFI), which compare the chi-square value to a baseline model and Tucker-Lewis Index (TLI) is a development of the Normed Fit Index (NFI) with more consideration to sampling size.

Results in Table 6 show a good fit for the measurement model compared to the cut-off points considered with the default model. Bentler (1990) found an acceptable value of RMSEA indicating good fit associated with PCLOSE less than 0.05; CFI, IFI, and TLI were very close to 0.9 , which is also acceptable (Emir, 2016). Chi-squared was also in the range $>1$ and $<5$ associated with a significant p-value.

Further, the study considered analyzing the path significance of each relationship, where it examined the standardized estimate (S.E), critical ratios (C.R), and p-value for the proposed hypothesis. A hypothesis is considered significant if a p-value is greater than 1.96 and a p-value less or equal to 0.05 . Therefore, to obtain a t-value, the regression weight estimates were divided by the S.E. Thus, the 
regression weight estimate of the hypothesis in this study presented in Table 7 indicates that all causal paths for the hypothesis were significant with the t-values above 1.96 and the p-value of less than 0.00 .

Table 6: Test for Suitability of the Structure Detection

\begin{tabular}{lll}
\hline Indices & Default Model & Suggested Criteria \\
\hline RMSEA & 0.054 & $<0.08$ \\
PCLOSE & 0.000 & $<0.05$ \\
\hline $\mathbf{X}^{2} / \mathbf{d f}$ & 3.654 & $1-5$ \\
$\mathbf{P}$ & 0.000 & $\leq 0.001$ \\
\hline CFI & 0.876 & Close to 0.9 \\
\hline IFI & 0.785 & Close to 0.9 \\
\hline TLI & .843 & Close to 0.9 \\
\hline
\end{tabular}

The study postulated no significant influence of socio-economic factors on students' choice to enrol in tourism education among public universities in Kenya. The associated regression weight (Table 7) shows a significant relationship between social-economic factors and students' choice to enrol in tourism education $(\beta=0.872 ; \mathrm{t}=9.176 ; \mathrm{p}<0.001)$. This indicates that an increase of 1 standard deviation in socio-economic factors is likely to lead to a corresponding rise of 9.176 standard deviations in students' choice to enrol in tourism education. Thus, the null hypothesis $\mathrm{H}_{0} 1$ is rejected, and the opposite is accepted, concluding that socio-economic factors significantly influence students' intention to enrol in tourism education.

Table 7: Summary of the Hypothesis Testing

\begin{tabular}{lllllll}
\hline Hypotheses & Variables & Estimate & S. E & C.R & $P$ & Decision \\
\hline $\mathbf{H}_{\mathbf{0}}$ & $\begin{array}{l}\text { Social-economic } \\
\text { factors- students } \\
\text { choice to enroll } \\
\text { nexus }\end{array}$ & .872 & .096 & 9.176 & 0.000 & Not Supported \\
& & & & & \\
$* * * p<0.001, * * p<0.01, * p<0.05$ t-value $>1.96$ & & &
\end{tabular}

\section{Discussions}

Social-economic factors stimulate various attributions on perceptions arising from an individual, family, parent's influence, or the larger community. They culminate as motivators in this study towards students' enrolment rate. The findings indicated that students strongly agreed that social-economic factors have a significant implication on students' decisions on the kind of courses they pursue in universities here in Kenya. These findings agree with those of Đurišić \& Bunijevac's (2017) study, who found a clear connection between parent's level of education and family income/wealth to their children's enrolment in postsecondary school education.

The majority of the students strongly agreed that employment prospects after graduation affected their decision to choose a tourism degree ( $\mathrm{M}=2.94, \mathrm{SD}=1.246)$. In line with this finding, Angulo et al. (2010) identified career opportunities as one of the factors affecting students' choices. This is because the job market in Kenya is saturated, and students face a more significant challenge of securing a job after graduation, marred by fierce competition and corruption. The new graduates have been competing with the old graduates in the same job pool, which led to high competition for potential jobs, with the unemployment rate in Kenya standing at $6.2 \%$ as of the first quarter of 2019 (KNBS, 2019). However, the job opportunities have not increased correspondingly with the increase of university graduates every year.

Another notable finding indicated that a degrees' tuition rates influence a prospectus student's enrolment (M=2.02, $\mathrm{SD}=0.954)$. While the institutions always want to maximize their revenue by increasing the cost of the courses they offer, study costs and tuition fees have been reported as one of the major factors influencing students' choice for their higher education institution (Saichaie, 2011). However, these findings contradict Çokgezen's (2014) study, which reported a non-significant relationship between the fee charged by an institution and the students' choice to enrol at the institution. Unfortunately, the cost of higher education continues to rise without any sign of slowing down shortly, which has a dramatic impact on prospective students, Baliyan (2016).

In the Kenyan context, government sponsorship and international scholarships have already been supporting students for higher studies. Despite the partial fee subsidy given by the HELB and bursaries from both County and National governments, students still need some amount of money (cater for accommodation, transport, books, among other needs), deemed expensive by low-income families. It, therefore, seems fair for such families to either acquire new means to pay in addition to their annual income or choose relatively low-cost education courses for their children.

For the above reason, Hoogeveena \& Rossi (2013) finds socio-economic, moreso financial resources a chief impediment to higher education. 


\section{Conclusion}

Socio-economic factors were statistically significant to the rate of enrolment among the twelve selected Kenyan public universities. This can be attributed to how socio-economic factors hugely touched on financial capabilities and prospects after being employed. These aspects essentially coin to the capitalist nature of the Kenyan society; monetary gains are put first in whatever investment one sinks into. Therefore, public universities in Kenya should embrace financial assistance to students; strive for partnerships with private and government entities to ensure students' fees. To some extent, students' living expenses are either partially or fully sponsored. This will go a long way to establishing a mutual relationship between students and the universities while boosting the enrolment numbers for tourism studies.

This research has been conducted among undergraduate students. It is recommended that further similar research be carried out among diplomas and postgraduate students for comparison purposes. Second, the study used a descriptive survey design with a crosssectional data collection technique. Therefore, the study recommends a longitudinal study where tourism students' perceptions and intentions of the industry would be evaluated before they are enrolled. Lastly, the participants were sampled from public universities only. This does not mean that tourism courses are not offered in private universities as well. Therefore, a comparative study should be conducted to establish the variables explored in this study, among private universities and colleges.

\section{References}

Angulo, F., Pergelova, A., \& Rialp, J. (2010). A market segmentation approach for higher education based on rational and emotional factors. Journal of Marketing for Higher Education, 20(1), 1-17.

Atef, M., Al-Balushi, M., \& Hamza, P. M. (2019). The Road to UNWTO.TedQual Certification A Documental Approach. Journal of Tourism and Hospitality Management, 7(1), 2372-5133. https://doi.org/10.15640/jthm.v7n1a3

Avery, C., \& Turner, S. (2012). Student loans: Do college students borrow too much or not enough. Journal of Economic Perspectives, 26(1), 165-192.

Baliyan, S. P. (2016). An Investigation into Factors Influencing Students' Choice to Enrol at Private Higher Education Institution in Botswana (Issue March). The University of South Africa.

Barwick, M., Dubrowski, R., \& Petricca, K. (2021). Knowledge Translation: The Rise of Implementation (Issue 11). American Institutes for Research. www.air.org

Becker, G. (1962). Investment in human capital: A theoretical analysis. Journal of Political Economy, 70(5), 9-49.

Becker, G. (1967). Human Capital: A Theoretical and Empirical Analysis with Special Reference to Education. Columbia University Press.

Becker, G., \& Tomes, N. (1986). Human Capital and the Rise and Fall of Families. Labour Economics, 4(3), 1-39.

Byrne, B. M. (2016). Structural Equation Modeling With AMOS: Basic Concepts, Applications, and Programming (3rd ed.). Routledge.

Cabrera, A., \& La Nasa, S. (2000). Using national databases to study the college choice of low-SES students.

Ceka, A., \& Murati, R. (2016). The Role of Parents in the Education of Children Ardita. Journal of Education and Practice, 7(5), 61-64. www.iiste.org

Chan, R., Brown, G., \& Ludlow, L. (2014). What is the purpose of higher education? : A comparison of institutional and student perspectives on the goals and purposes of completing a bachelor's degree in the 21st century.

Çokgezen, M. (2014). Determinants of University Choice: A Study on Economics Departments in Turkey. Yuksekogretim Dergisi, 4(1), 23-31. https://doi.org/10.2399/yod.14.002

Commission of Universty Education. (2016). State of University Education in Kenya (2015/2016). In E. J. Mukhwana (Ed.), Commission of University Education (1st ed.). Ministry of Education.

Commission for University Education. (2018). Commission for university education university statistics (2016/2017). In Commission for University Education (2nd ed.). http://www.cue.or.ke/

Cronk, B. C. (2018). How to use SPSS. A Step-By-Step Guide to Analysis and Interpretation. In Journal of Chemical Information and Modeling (10th ed., Vol. 53, Issue 9). Routledge: Taylor \& Francis Group.

Dahari, Z., \& Abduh, M. (2011). Factors Influencing International Students' Choice Towards Universities in Malaysia. African Journal of Business Management, 5(26), 10615-10620.

Đurišić, M., \& Bunijevac, M. (2017). Parental Involvement as an Important Factor for Successful Education. C.E.P.S Journal, 7(3), 137-153.

Ekpo, E. O., \& Igiri, C. (2015). The Influence of family background on the academic achievement of students in basic science. International Letters of Social and Humanistic Sciences, $59(9), \quad 20-27$. https://doi.org/10.18052/www.scipress.com/ILSHS.59.20

Emir, O. (2016). A study of the relationship between service atmosphere and customer loyalty with specific reference to structural equation modelling. Conomic Research-Ekonomska Istraživanja, $29(1), \quad 706-720$. https://doi.org/10.1080/1331677X.2016.1195276

Fan, Y., Chen, J., Shirkey, G., John, R., Wu, S. R., Park, H., \& Shao, C. (2016). Applications of structural equation modelling (SEM) in ecological studies: an updated review. Ecological Processes, 5(1), 5-19. https://doi.org/10.1186/s13717-016-0063-3 
Fleischhauer, K.-J. (2011). A Review of Human Capital Theory: Microeconomics. SSRN Electronic Journal, 1-50. https://doi.org/10.2139/ssrn.957993

Foskett, N., Roberts, D., \& Maringe, F. (2006). Changing fee regimes and their impacts on students' attitudes to higher education.

Gichuhi, L., \& Kibui, A. (2015). Individual Factors Influencing Demand for School Based-Module II Programs at the University of Nairobi. Journal of Educational Policy and Entrepreneurial Research (JEPER), 2(3), 101-107.

Haveman, R., \& Wolfe, B. (1995). The determinants of children's attainments: a review of methods and findings. Journal of Economic Literature, 33, 1829-1847.

Hoogeveena, J., \& Rossi, M. (2013). Enrolment and grade attainment following the introduction of free primary education in Tanzania. Journal of African Economies, 22(3), 375-393. https://doi.org/10.1093/jae/ejt003

Hu, S., \& Hossler, D. (2000). Willingness to pay preference for private institutions. Research in Higher Education, 41(6), 685-701.

Katwii, K. R. (2016). Parental characteristics influence the enrolment of pre-school children in Mwing Zone, Mwingi Sub-County, Kitui County. The University of Nairobi.

Kennett, D., Reed, M., \& Lam, D. (2011). The importance of directly asking students their reasons for attending higher education. Issues in Educational Research, 21(1), 65-75.

Kenya National Bureau of Statistics. (2019). 2019 Kenya Population and Housing Census : Population by County and Sub-County: Vol. I (Issue 11). http://www.knbs.or.ke

Kenya National Bureau of Statistics. (2020). Economic survey 2020. In Kenya National Bureau of Statistics. http://www.knbs.or.ke

Kromydas, T. (2017). Rethinking higher education and its relationship with social inequalities: Past knowledge, present state and future potential. Palgrave Communications: Journal of Humanities, Social Sciences, and Business, 3(1), 1-12. https://doi.org/10.1057/s41599-017-0001-8

Landry, S. H. (2014). The role of parents in early childhood learning. Encyclopedia on Early Childhood Development, 1(2), 1-6.

Li, Z., \& Qiu, Z. (2018). How does family background affect children's educational achievement? Evidence from Contemporary China. Journal of Chinese Sociology, 5(1). https://doi.org/10.1186/s40711-018-0083-8

Lyu, M., Li, W., \& Xie, Y. (2019). The influences of family background and structural factors on children's academic performances: A cross-country comparative study. Chinese Journal of Sociology, 5(2), $173-192$. https://doi.org/10.1177/2057150X19837908

Manono, D., Kieti, D., \& Momanyi, S. (2013). Mushrooming of Middle-Level Tourism \& Hospitality in Kenya. Journal of Education and Practice, 4(2), 57-65.

Maringe, F. (2006). University and choice course: Implications for positioning, recruitment, and marketing. International Journal of Educational Management, 20(6), 466-479.

Mayaka, M.A. \& Akama, J. . (2015).Challenges for the tourism, hospitality and events higher education curricula in Sub-Saharan Africa. In D. Dredge, D. Airey, \& M. . Gross (Eds.), Routledge Handbook of Tourism and Hospitality (pp. 72-98). Routledge.

Mayaka, M., \& Akama, J. S. (2007). Systems approach tourism training and education: The Kenyan case study. Tourism Management, 28(1), 298-306. https://doi.org/10.1016/j.tourman.2005.12.023

Mazzarol, T., \& Soutar, G. (2002). Push-pull factors influencing international students' destination choice. The International Journal of Educational Management, 16(2), 82-90.

McArthur. (2011). Reconsidering the social and economic purposes of higher education. Higher Education and Development, 30(6), 737-749.

Migin, M., Falahat, M., Yajid, M., \& Khatibi, A. (2015). Impacts of Institutional Characteristics on International Students' Choice of Private Higher Education Institutions in Malaysia. Higher Education Studies, 5(1), 31-42.

Mirashrafi, S. B., Bol, G., \& Nakhaiezadeh, G. (2013). The Effect of Family Background and Socioeconomic Status on Academic Performance of Higher Education Applicants. International Journal of Technology and Inclusive Education, 2(1), 130-138. https://doi.org/10.20533/ijtie.2047.0533.2013.0019

Mubaira, T., \& Olawale, F. (2012). The determinants of the choice of universities by foreign business students in South Africa. Asian Journal of Business and Management Sciences, 1(8), 2047-2528.

Muthoni, K. L. (2013). Relationship between family background and academic performance of secondary school students: a case of Siakago Division, Mbeere North District, Kenya. The University of Nairobi.

Orcan, F. (2018). Exploratory and Confirmatory Factor Analysis: Which One to Use First? Journal of Measurement and Evaluation in Education and Psychology, 9(4), 414-421. https://doi.org/10.21031/epod.394323

Osuafor, A., \& Okonkwo, I. (2013). Influence of Family Background on Academic Achievement of Secondary School Biology Students in Anambra State. African Research Review, 7(3). https://doi.org/10.4314/afrrev.v7i3.12

Ouma, W. O. F. (2018). Influence of parents' socio-economic status on enrolment and participation of children in Pre-primary schools in Busia County, Kenya. Kenyatta University.

Owusu, G. M. Y., Essel-Anderson, A., Ossei Kwakye, T., Bekoe, R. A., \& Ofori, C. G. (2018). Factors influencing career choice of tertiary students in Ghana: A comparison of science and business majors. Education and Training, 60(9), 992-1008. https://doi.org/10.1108/ET-04-2017-0050

Padlee, S., Kamaruddin, A., \& Baharun, R. (2010). International students' choice behaviour for higher education at Malaysian private universities. International Journal of Marketing, 2(2), 202-211.

Saichaie, K. (2011). Representation on college and university websites [University of Iowa]. https://doi.org/10.17077/etd.10xrp42m 
Sanyal, B., \& Martin, M. (1998). Management of Higher Education with Special Reference to Financial Management in African Countries (Vol. 20, Issue April). International Institute for Educational Planning. http://www.unesco.org/iiep

Saroush, M., Arefi, M., \& Yamani, M. (2015). Identifying the economic factors affecting the social demand for the higher education of postgraduate students of the Ferdowsi University of Mashhad. Journal of Applied Environmental and Biological Sciences, $5(10), 37-41$.

Tadaro, P., \& Smith, C. (2015). Economic Development (12th ed.). Pearson.

Teixeira, P. N. (2014). Gary Becker's early work on human capital - collaborations and distinctiveness. IZA Journal of Labor Economics, 3(1), 0-20. https://doi.org/10.1186/s40172-014-0012-2

Tytingvåg, S. (2015). The demand for education in Norway: An empirical analysis of education expenditures [University of Stavanger]. https://uis.brage.unit.no/uis-xmlui/handle/11250/299040

Wagner, K., \& Fard, P. (2009). Factors influencing Malaysian students' intention to study at a higher educational institution. ELeader Kuala Lumpur, 1-12.

Weidman, J. (1995). Diversifying Finance of Higher Education Systems of Higher Education in the Third World: The Case of Kenya and Mongolia. Education Policy Analysis Archives, 3(5), 1-13. https://doi.org/10.14507/epaa.v3n5.1995

Publisher's Note: SSBFNET stays neutral with regard to jurisdictional claims in published maps and institutional affiliations.

\section{(a) (1)}

(C) 2021 by the authors. Licensee SSBFNET, Istanbul, Turkey. This article is an open access article distributed under the terms and conditions of the Creative Commons Attribution (CC BY) license (http://creativecommons.org/licenses/by/4.0/).

International Journal of Research in Business and Social Science (2147-4478) by SSBFNET is licensed under a Creative Commons Attribution 4.0 International License. 